\title{
Imaging outcome measures of neuroprotection and repair in $\mathrm{MS}$
}

\author{
A consensus statement from NAIMS
}

\begin{abstract}
Jiwon Oh, MD, PhD, FRCPC, Daniel Ontaneda, MD, Christina Azevedo, MD, Eric C. Klawiter, MD, MSc, Martina Absinta, Douglas L. Arnold, MD, FRCPC, Rohit Bakshi, MD, MA, Peter A. Calabresi, MD, Ciprian Crainiceanu, PhD, Blake Dewey, Leorah Freeman, MD, PhD, Susan Gauthier, DO, MPH, Roland Henry, PhD, Mathilde Inglese, MD, PhD,

Shannon Kolind, PhD, David K.B. Li, MD, FRCPC, Caterina Mainero, MD, PhD, Ravi S. Menon, PhD, Govind Nair, PhD, Sridar Narayanan, PhD, Flavia Nelson, MD, Daniel Pelletier, MD, Alexander Rauscher, PhD, William Rooney, PhD, Pascal Sati, PhD, Daniel Schwartz, PhD, Russell T. Shinohara, PhD, lan Tagge, PhD, Anthony Traboulsee, PhD, Yi Wang, PhD, Youngjin Yoo, PhD, Tarek Yousry, MD, Yunyan Zhang, PhD, Nancy L. Sicotte, MD, and Daniel S. Reich, MD, PhD, on behalf of the North American Imaging in Multiple Sclerosis Cooperative
\end{abstract}

Neurology ${ }^{\circledR}$ 2019;92:519-533. doi:10.1212/WNL.0000000000007099

\section{Abstract}

\section{Objective}

To summarize current and emerging imaging techniques that can be used to assess neuroprotection and repair in multiple sclerosis (MS), and to provide a consensus opinion on the potential utility of each technique in clinical trial settings.

\section{Methods}

Clinicians and scientists with expertise in the use of MRI in MS convened in Toronto, Canada, in November 2016 at a North American Imaging in Multiple Sclerosis (NAIMS) Cooperative workshop meeting. The discussion was compiled into a manuscript and circulated to all NAIMS members in attendance. Edits and feedback were incorporated until all authors were in agreement.

\section{Results}

A wide spectrum of imaging techniques and analysis methods in the context of specific study designs were discussed, with a focus on the utility and limitations of applying each technique to assess neuroprotection and repair. Techniques were discussed under specific themes, and included conventional imaging, magnetization transfer ratio, diffusion tensor imaging, susceptibility-weighted imaging, imaging cortical lesions, magnetic resonance spectroscopy, PET, advanced diffusion imaging, sodium imaging, multimodal techniques, imaging of special regions, statistical considerations, and study design.

\section{Conclusions}

Imaging biomarkers of neuroprotection and repair are an unmet need in MS. There are a number of promising techniques with different strengths and limitations, and selection of a specific technique will depend on a number of factors, notably the question the trial seeks to answer. Ongoing collaborative efforts will enable further refinement and improved methods to image the effect of novel therapeutic agents that exert benefit in MS predominately through neuroprotective and reparative mechanisms.

\author{
Correspondence \\ Dr. Oh \\ ohjiw@smh.ca
}

\footnotetext{
From the Division of Neurology (J.O.), St. Michael's Hospital, University of Toronto, Canada; Department of Neurology (J.O., P.A.C., B.D., D.S.R.), Johns Hopkins University, Baltimore, MD; Mellen Center for Multiple Sclerosis (D.O.), Cleveland Clinic, OH; Department of Neurology (C.A., D.P.), University of Southern California, Los Angeles; Department of Neurology (E.C.K.), Massachusetts General Hospital, Harvard Medical School, Boston; Translational Neuroradiology Unit (M.A., G.N., P.S., D.S.R.), National Institute of Neurological Disorders and Stroke, Bethesda, MD; Brain Imaging Centre (D.L.A., S.N.), Montreal Neurological Institute, McGill University, Canada; Departments of Neurology (R.B.) and Radiology (R.B.), Brigham and Women's Hospital, Harvard Medical School, Boston; Department of Biostatistics (C.C.), Johns Hopkins School of Public Health, Baltimore, MD; Department of Neurology (L.F.), University of Texas Health Science Center at Houston; Department of Neurology (S.G., Y.W.), Weill Cornell Medical College, Cornell University, Ithaca, NY; Department of Neurology (R.H.), University of California at San Francisco; Department of Neurology (M.I., A.T.), Mount Sinai Hospital, New York, NY; Division of Neurology, Department of Medicine (S.K., D.K.B.L.), Department of Radiology (S.K., D.K.B.L., A.R.), Department of Physics and Astronomy (S.K., A.R., A.T., Y.Y.), MS/MRI Research Group (S.K., D.K.B.L., A.T., Y.Y.), MRI Research Centre (S.K., D.K.B.L., A.R.), and Department of Pediatrics (A.R.), University of British Columbia, Vancouver, Canada; A. A. Martinos Center for Biomedical Imaging (C.M.), Department of Radiology, Massachusetts General Hospital, Boston; Centre for Functional and Metabolic Mapping (R.S.M.), Robarts Research Institute, Western University, London, CA; Department of Neurology (F.N.), University of Minnesota, Minneapolis; Advanced Imaging Research Center (W.R., D.S., I.T.), Oregon Health \& Science University, Portland; Department of Biostatistics, Epidemiology, and Informatics (R.T.S.), University of Pennsylvania Perelman School of Medicine, Philadelphia; Division of Neuroradiology and Neurophysics (T.Y.), University College London Institute of Neurology, UK; Department of Radiology (Y.Z.) and Department of Clinical Neurosciences and Hotchkiss Brain Institute (Y.Z.), University of Calgary, Canada; and Department of Neurology (N.L.S.), Cedars-Sinai Medical Center, Los Angeles, CA.

The North American Imaging in Multiple Sclerosis Cooperative coinvestigators are available at Iww.com/WNL/A852.
}

Go to Neurology.org/N for full disclosures. Funding information and disclosures deemed relevant by the authors, if any, are provided at the end of the article. 


\section{Glossary}

ATP = adenosine triphosphate; DMT = disease-modifying treatment; DTI = diffusion tensor imaging; FLAIR = fluidattenuated inversion recovery; GCIP = ganglion cell + inner plexiform layer; $\mathbf{G M}=$ gray matter; ISC = intracellular sodium concentration; LME = leptomeningeal enhancement; $\mathbf{M R}=$ magnetic resonance; $\mathbf{M R S}$ = magnetic resonance spectroscopy; MS = multiple sclerosis; MTR = magnetization transfer ratio; $\mathbf{M W F}=$ myelin water fraction; $\mathbf{M W I}=$ myelin water imaging; NAA $=N$-acetylaspartate; NAIMS $=$ North American Imaging in Multiple Sclerosis; NODDI $=$ neurite orientation dispersion and density imaging; OCT = optical coherence tomography; $\mathbf{p R N F L}=$ peripapillary retinal nerve fiber layer thickness; $\mathbf{Q S M}=$ quantitative susceptibility mapping; RD = radial diffusivity; RRMS = relapsing-remitting multiple sclerosis; $\mathbf{S C}=$ spinal cord; SWI $=$ susceptibility-weighted imaging; TSC $=$ total sodium concentration; TSPO = translocator protein; WM $=$ white matter.

The treatment landscape for multiple sclerosis (MS) has changed dramatically, with a substantial increase in the number of disease-modifying treatments (DMTs). DMTs that exert beneficial effects through neuroprotective or neurorepair mechanisms are the new frontier of MS therapeutics, and developing accurate imaging measures of neuroprotection and repair for proof-of-concept clinical trials is an unmet need. This consensus statement builds upon prior reports $^{1}$ and summarizes current and emerging imaging techniques to assess neuroprotection and repair, discusses the advantages and disadvantages of each technique, and provides a consensus opinion on the potential utility of each technique in clinical trials, based on up-to-date evidence and expert opinion.

\section{Methods}

Clinicians and scientists with expertise in the use of MRI in MS convened in Toronto, Canada, in November 2016 at a North American Imaging in Multiple Sclerosis (NAIMS) Cooperative workshop meeting. ${ }^{2}$ A wide spectrum of imaging techniques was discussed in the context of specific study designs, with a focus on the utility and limitations of applying each technique to assess neuroprotection and repair. The discussion was compiled into a manuscript and circulated to all members in attendance. Edits and feedback were incorporated until all authors were in agreement.

\section{General discussion points}

This summary distinguishes between repair and neuroprotection, recognizing that strategies aiming to repair tissue damage could also be considered neuroprotective. ${ }^{3}$ Here, "repair" refers to strategies aiming to reverse tissue damage and "neuroprotection" to strategies aiming to prevent neuroaxonal loss. The focus is on measures with group-level utility; application in individual patients is a clear limitation of most of the techniques discussed. Whole-brain atrophy, currently the most widely used method in MS clinical trials to measure disease progression and potentially neuroprotection, has been reviewed extensively elsewhere ${ }^{4, \mathrm{e} 1}$; the focus here is on emerging techniques specifically discussed at the workshop. Key points are summarized in table 1 .

\section{Repair of acute white matter (WM) lesions}

Recovery of tissue integrity months after acute lesion formation in MS includes both remyelination and axonal repair. ${ }^{5}$ Imaging this recovery process is important for the evaluation of experimental agents that promote repair.

\section{Conventional imaging}

Historically, the most commonly applied MRI measure of acute lesion repair is monitoring $\mathrm{T} 1$ hypointensity evolution over time; lesions that show substantial residual tissue damage demonstrate persistent $\mathrm{T} 1$ hypointensity (black holes). ${ }^{6}$ At the time of lesion formation, most lesions show $\mathrm{T} 1$ hypointensity due to edema, and persistence of $\mathrm{T} 1$ hypointensity pathologically correlates with loss of axons. ${ }^{\mathrm{e} 2}$ Clinical trials often use reduced conversion of acute lesions to black holes to demonstrate a protective effect of DMTs. An effect on black hole conversion and black hole volume has been demonstrated in clinical trials with $\beta$-interferon, ${ }^{\mathrm{e} 3}$ glatiramer acetate, natalizumab, ${ }^{\mathrm{e} 4}$ fingolimod, ${ }^{\mathrm{e} 5}$ dimethyl fumarate, ${ }^{\mathrm{e} 6}$ teriflunomide, ${ }^{\mathrm{e} 7}$ alemtuzumab, ${ }^{\mathrm{e} 8}$ and ocrelizumab. ${ }^{\mathrm{e} 9}$ However, a limitation of the detection of black holes is that it is highly dependent on MRI sequence and field strength used. ${ }^{\text {10 }}$ Gadolinium enhancement patterns have also been used to determine the evolution of lesions and may relate indirectly to repair. The presence of nodular vs ring enhancement has been considered, and the centripetal dynamic pattern of enhancement has been proposed to signify incipient lesion repair. ${ }^{7, \mathrm{e} 11}$ The relative intensity of signal change has also been used as a marker for tissue repair, ${ }^{8}$ and sample size estimates using proton density-weighted signal have been published. ${ }^{\mathrm{e} 2}$ Postmortem examination shows good correlation between proton density signal intensity and myelin. ${ }^{\mathrm{e} 13}$ Conventional MRI measures leverage the routine collection of such data on scanners in wide clinical use. The largest drawback is that the measures lack pathologic specificity and require signal normalization., ${ }^{90, \mathrm{e} 14-\mathrm{e} 17}$ The greatest utility of these techniques may be the ability to demonstrate a failure to exert neuroprotective or reparative effects.

\section{Magnetization transfer ratio (MTR)}

MTR is a semi-quantitative index sensitive to myelin that measures the exchange of magnetization between protons bound in macromolecules-in WM, commonly myelin membrane constituents-to unrestricted protons in free water. 
Table 1 Proposed imaging techniques of neuroprotection and repair

\begin{tabular}{|c|c|c|c|c|c|c|c|}
\hline $\begin{array}{l}\text { Imaging } \\
\text { technique }\end{array}$ & Imaging target & $\begin{array}{l}\text { Potential utility } \\
\text { in assessing } \\
\text { neuroprotection } \\
\text { or repair }\end{array}$ & Advantages & $\begin{array}{l}\text { Specificity for imaging } \\
\text { target }\end{array}$ & Sensitivity to change & Limitations & Likely setting for use \\
\hline $\begin{array}{l}\text { Conventional } \\
\text { MRI measures in } \\
\text { acute lesions }\end{array}$ & Myelin integrity & Repair & $\begin{array}{l}\text { Required sequences } \\
\text { routinely acquired on } \\
\text { commercial scanners }\end{array}$ & $\begin{array}{l}\text { Low, one pathologic study } \\
\text { showing good correlation } \\
\text { with myelin } \\
\text { measures }\end{array}$ & $\begin{array}{l}\text { High, as demonstrated } \\
\text { by acute lesion studies, } \\
\text { with relatively small } \\
\text { sample size } \\
\text { calculations } \\
7,8, \mathrm{e} 11, \mathrm{e} 12\end{array}$ & $\begin{array}{l}\text { Lack specificity, require } \\
\text { normalization }\end{array}$ & $\begin{array}{l}\text { Large (phase III) clinical } \\
\text { trials assessing } \\
\text { remyelination; proof-of- } \\
\text { concept trials for futility } \\
\text { assessment }\end{array}$ \\
\hline $\begin{array}{l}\text { Magnetization } \\
\text { transfer imaging }\end{array}$ & Myelin integrity & Repair & $\begin{array}{l}\text { Implementable on most } \\
\text { commercial scanners, } \\
\text { reasonable acquisition times, } \\
\text { high precision, simple } \\
\text { postacquisition processing } \\
\text { algorithm, reasonable } \\
\text { sample sizes for clinical trials }\end{array}$ & $\begin{array}{l}\text { Moderate, up to } 30 \% \text { of low } \\
\text { MTR lesions may have } \\
\text { normal myelin content }{ }^{11,} \text { e } 18\end{array}$ & $\begin{array}{l}\text { High, predictable } \\
\text { dynamic in acute } \\
\text { lesions }^{12,13,15, \mathrm{e} 20-\mathrm{e} 23}\end{array}$ & $\begin{array}{l}\text { Not entirely specific to myelin, } \\
\text { nonlinear relationship to myelin } \\
\text { density, calibration required } \\
\text { across and within scanners }\end{array}$ & $\begin{array}{l}\text { Large (phase III) clinical } \\
\text { trials assessing } \\
\text { remyelination; proof-of- } \\
\text { concept trials }\end{array}$ \\
\hline $\begin{array}{l}\text { Diffusion tensor } \\
\text { imaging }\end{array}$ & Myelin integrity & Repair & $\begin{array}{l}\text { Sensitive to myelin content, } \\
\text { measurable recovery, } \\
\text { potential utility in multicenter } \\
\text { settings }\end{array}$ & $\begin{array}{l}\text { Low, dependent on regional } \\
\text { factors such as crossing } \\
\text { fibers and underlying tissue } \\
\text { architecture } \mathrm{e}^{25, \mathrm{e} 76}\end{array}$ & $\begin{array}{l}\text { High, predictable } \\
\text { pattern with formation } \\
\text { of new lesions; shows } \\
\text { good recovery in animal } \\
\text { studies of } \\
\text { demyelination }^{17, e 26}\end{array}$ & $\begin{array}{l}\text { Poor specificity, cumbersome } \\
\text { data acquisition and analysis }\end{array}$ & $\begin{array}{l}\text { Single or multicenter } \\
\text { clinical trials assessing } \\
\text { remyelination }\end{array}$ \\
\hline $\begin{array}{l}\text { Myelin water } \\
\text { imaging }\end{array}$ & Myelin integrity & $\begin{array}{l}\text { Neuroprotection } \\
\text { and repair }\end{array}$ & $\begin{array}{l}\text { High specificity for myelin } \\
\text { when corrected for changes } \\
\text { in total water content, good } \\
\text { intrasite and intersite } \\
\text { reliability, reproducibility } \\
\text { across platforms }\end{array}$ & $\begin{array}{l}\text { High, pathologic studies } \\
\text { show strong sensitivity to } \\
\text { myelin but if uncorrected, } \\
\text { may be affected by changes } \\
\text { in total water } \\
\text { content }^{22,24, e 36}\end{array}$ & $\begin{array}{l}\text { High, recovery in } \\
\text { enhancing lesions, } \\
\text { progressive increase in } \\
\text { new contrast- } \\
\text { enhancing lesions, } \\
\text { change detectable in } \\
\text { global white } \\
\text { matter } 20,21, e 35, \mathrm{e} 148\end{array}$ & $\begin{array}{l}\text { Historically, relatively long } \\
\text { acquisition times, lower signal to } \\
\text { noise }\end{array}$ & $\begin{array}{l}\text { Single or multicenter } \\
\text { clinical trials assessing } \\
\text { remyelination }\end{array}$ \\
\hline $\begin{array}{l}\text { Susceptibility- } \\
\text { weighted } \\
\text { imaging (phase } \\
\text { and QSM/T2* } \\
\text { weighted) }\end{array}$ & $\begin{array}{l}\text { Macrophages, } \\
\text { microglia, iron } \\
\text { accumulation, } \\
\text { myelin integrity }\end{array}$ & $\begin{array}{l}\text { Neuroprotection } \\
\text { and repair }\end{array}$ & $\begin{array}{l}\text { High spatial resolution and } \\
\text { high signal-to-noise ratio }\end{array}$ & $\begin{array}{l}\text { Moderate-high for iron and } \\
\text { myelin contrast; some } \\
\text { lesions have a QSM- } \\
\text { hyperintense rim, which } \\
\text { may be related to iron/ } \\
\text { microglia }{ }^{29}\end{array}$ & $\begin{array}{l}\text { High, changes relate to } \\
\text { biology of lesions, } \\
\text { chronic active vs } \\
\text { inactive vs active }\end{array}$ & $\begin{array}{l}\text { Variable acquisition protocols } \\
\text { with differential sensitivity; } \\
\text { results may be affected by } \\
\text { changes in neighboring } \\
\text { structures ("nonlocal effects"), } \\
\text { need postprocessing of standard } \\
\text { 3D multiecho gradient echo data }\end{array}$ & $\begin{array}{l}\text { Early, single or multicenter } \\
\text { clinical trials assessing } \\
\text { neuroprotection and } \\
\text { remyelination }\end{array}$ \\
\hline $\begin{array}{l}\text { Cortical lesion } \\
\text { detection }\end{array}$ & $\begin{array}{l}\text { Cortical lesions, } \\
\text { cortical myelin } \\
\text { integrity }\end{array}$ & $\begin{array}{l}\text { Neuroprotection } \\
\text { and repair }\end{array}$ & $\begin{array}{l}\text { Highly relevant clinically, } \\
\text { dedicated sequences at } \\
\text { clinical field strengths can } \\
\text { detect lesions, } \\
\text { semiquantitative and } \\
\text { quantitative magnetic } \\
\text { resonance contrasts can be } \\
\text { applied to cortex }\end{array}$ & $\begin{array}{l}\text { Moderate, dependent on } \\
\text { MRI field strength, lesion } \\
\text { type, and sequence }{ }^{39,448}\end{array}$ & $\begin{array}{l}\text { Moderate-high } \\
\text { (particularly at 7T) } \\
\text { e149,e150 }\end{array}$ & $\begin{array}{l}\text { Difficult to detect subpial lesions, } \\
\text { limited availability of 7T MRI }\end{array}$ & $\begin{array}{l}\text { Early single or multicenter } \\
\text { clinical trials assessing } \\
\text { neuroprotection and } \\
\text { remyelination }\end{array}$ \\
\hline
\end{tabular}


Table 1 Proposed imaging techniques of neuroprotection and repair (continued)

\begin{tabular}{|c|c|c|c|c|c|c|c|}
\hline $\begin{array}{l}\text { Imaging } \\
\text { technique }\end{array}$ & Imaging target & $\begin{array}{l}\text { Potential utility } \\
\text { in assessing } \\
\text { neuroprotection } \\
\text { or repair }\end{array}$ & Advantages & $\begin{array}{l}\text { Specificity for imaging } \\
\text { target }\end{array}$ & Sensitivity to change & Limitations & Likely setting for use \\
\hline $\begin{array}{l}\text { Magnetic } \\
\text { resonance } \\
\text { spectroscopy }\end{array}$ & $\begin{array}{l}\text { Neuronal } \\
\text { integrity, } \\
\text { energy/ } \\
\text { metabolism }\end{array}$ & Neuroprotection & $\begin{array}{l}\text { Has potential to reflect the } \\
\text { underlying biology of disease, } \\
\text { and to identify tissue at risk } \\
\text { for neurodegeneration }\end{array}$ & $\begin{array}{l}\text { Moderate-high, dependent } \\
\text { on } \\
\text { metabolite }^{41-43, e 60, e 61, e 73, e 74}\end{array}$ & $\begin{array}{l}\text { Low-moderate, change } \\
\text { detectable in small } \\
\text { studies }^{1151}\end{array}$ & $\begin{array}{l}\text { Limited reproducibility, variability } \\
\text { across scanners, low spatial } \\
\text { resolution, challenges with } \\
\text { quantification, limited availability }\end{array}$ & $\begin{array}{l}\text { Early, single-center clinical } \\
\text { trials assessing } \\
\text { neuroprotection }\end{array}$ \\
\hline $\begin{array}{l}\text { Advanced } \\
\text { diffusion- } \\
\text { weighted } \\
\text { imaging }\end{array}$ & Axonal integrity & Neuroprotection & $\begin{array}{l}\text { Compartment-specific } \\
\text { modeling of water that } \\
\text { enables quantitative } \\
\text { assessment of axon density } \\
\text { with improved specificity to } \\
\text { tissue microstructural } \\
\text { changes }\end{array}$ & $\begin{array}{l}\text { Unclear: theoretically high, } \\
\text { but validation studies } \\
\text { needed }{ }^{45, \text { e } 77-e 80}\end{array}$ & Unclear & $\begin{array}{l}\text { Insensitive at probing small- } \\
\text { diameter axons at conventional } \\
\text { gradient strength, multicenter } \\
\text { application a challenge as high- } \\
\text { gradient systems are scarce }\end{array}$ & $\begin{array}{l}\text { Early, single-center clinical } \\
\text { trials assessing } \\
\text { neuroprotection }\end{array}$ \\
\hline Sodium imaging & Axonal function & Neuroprotection & $\begin{array}{l}\text { Reflects axonal dysfunction, } \\
\text { can provide insights into } \\
\text { axonal metabolism before } \\
\text { the generation of stable, } \\
\text { irreversible, axonal damage }\end{array}$ & $\begin{array}{l}\text { Moderate, dependent on } \\
\text { MRI field strength, and } \\
\text { sequence }{ }^{46, e 82}\end{array}$ & Unknown & $\begin{array}{l}\text { Low spatial resolution, limited } \\
\text { availability of } 7 \mathrm{~T} \text { MRI }\end{array}$ & $\begin{array}{l}\text { Early, single-center clinical } \\
\text { trials assessing } \\
\text { neuroprotection }\end{array}$ \\
\hline $\begin{array}{l}\text { Multimodal } \\
\text { imaging (in vivo } \\
\text { g-ratio } \\
\text { estimation) }\end{array}$ & $\begin{array}{l}\text { Myelin and } \\
\text { axonal integrity }\end{array}$ & $\begin{array}{l}\text { Neuroprotection } \\
\text { and repair }\end{array}$ & $\begin{array}{l}\text { Incorporates information } \\
\text { about myelin and axonal } \\
\text { integrity, which can influence } \\
\text { one another }\end{array}$ & $\begin{array}{l}\text { Unclear: theoretically high, } \\
\text { but validation studies } \\
\text { needed }^{\text {e83,84 }}\end{array}$ & Unclear & $\begin{array}{l}\text { Limited availability of necessary } \\
\text { technical expertise }\end{array}$ & $\begin{array}{l}\text { Early, single-center proof- } \\
\text { of-concept clinical trials } \\
\text { assessing } \\
\text { neuroprotection and } \\
\text { repair }\end{array}$ \\
\hline $\begin{array}{l}\text { Thalamic } \\
\text { volume }\end{array}$ & $\begin{array}{l}\text { Myelin integrity, } \\
\text { axonal loss }\end{array}$ & Neuroprotection & $\begin{array}{l}\text { Highly relevant clinically, can } \\
\text { act as a barometer of overall } \\
\text { tissue damage in MS, } \\
\text { practical sample sizes }\end{array}$ & $\begin{array}{l}\text { Low: nonspecific } \\
\text { measure }{ }^{48, e 88, e 91}\end{array}$ & $\mathrm{High}^{49}$ & Measurement variability & $\begin{array}{l}\text { Phase II/III clinical trials } \\
\text { assessing } \\
\text { neuroprotection }\end{array}$ \\
\hline $\begin{array}{l}\text { Hippocampal } \\
\text { atrophy }\end{array}$ & $\begin{array}{l}\text { Myelin integrity, } \\
\text { axonal loss }\end{array}$ & Neuroprotection & $\begin{array}{l}\text { Has potential as a sensitive } \\
\text { and specific primary } \\
\text { endpoint for studies focused } \\
\text { on memory impairment and } \\
\text { depression in MS }\end{array}$ & $\begin{array}{l}\text { Low: nonspecific } \\
\text { measure } \mathrm{e}^{\mathrm{e} 103, \mathrm{e} 105, \mathrm{e} 107}\end{array}$ & $\begin{array}{l}\text { Moderate: change } \\
\text { detectable in small } \\
\text { studies }^{\mathrm{e} 152}\end{array}$ & Requires additional validation & $\begin{array}{l}\text { Early, single-center } \\
\text { studies focusing on } \\
\text { cognition and mood }\end{array}$ \\
\hline $\begin{array}{l}\text { Spinal cord } \\
\text { atrophy }\end{array}$ & $\begin{array}{l}\text { Myelin integrity, } \\
\text { axonal loss }\end{array}$ & Neuroprotection & $\begin{array}{l}\text { Highly relevant clinically, } \\
\text { particularly in progressive MS }\end{array}$ & $\begin{array}{l}\text { Low: nonspecific } \\
\text { measure } \mathrm{e}^{153, \mathrm{e} 154}\end{array}$ & $\begin{array}{l}\text { High: change } \\
\text { measurable over } \\
\text { time } \mathrm{e}^{\mathrm{e} 119}\end{array}$ & Measurement variability & $\begin{array}{l}\text { Single or multicenter } \\
\text { clinical trials assessing } \\
\text { neuroprotection, } \\
\text { particularly in progressive } \\
\text { MS }\end{array}$ \\
\hline $\begin{array}{l}\text { Spinal cord: } \\
\text { advanced } \\
\text { imaging }\end{array}$ & $\begin{array}{l}\text { Myelin integrity, } \\
\text { axonal loss }\end{array}$ & $\begin{array}{l}\text { Neuroprotection } \\
\text { and repair }\end{array}$ & $\begin{array}{l}\text { More sensitive and specific to } \\
\text { underlying tissue } \\
\text { microstructural changes than } \\
\text { conventional techniques }\end{array}$ & $\begin{array}{l}\text { Moderate: based on } \\
\text { pathologic correlations }\end{array}$ & $\begin{array}{l}\text { High: change } \\
\text { measurable over time }\end{array}$ & $\begin{array}{l}\text { Measurement variability, } \\
\text { complexity of image analysis }\end{array}$ & $\begin{array}{l}\text { Not yet ready for use in } \\
\text { clinical trials }\end{array}$ \\
\hline
\end{tabular}




\section{Table 1 Proposed imaging techniques of neuroprotection and repair (continued)}

\begin{tabular}{|c|c|c|c|c|c|c|c|}
\hline $\begin{array}{l}\text { Imaging } \\
\text { technique }\end{array}$ & Imaging target & $\begin{array}{l}\text { Potential utility } \\
\text { in assessing } \\
\text { neuroprotection } \\
\text { or repair }\end{array}$ & Advantages & $\begin{array}{l}\text { Specificity for imaging } \\
\text { target }\end{array}$ & Sensitivity to change & Limitations & Likely setting for use \\
\hline $\begin{array}{l}\text { Leptomeningeal } \\
\text { enhancement }\end{array}$ & $\begin{array}{l}\text { Leptomeningeal } \\
\text { inflammation }\end{array}$ & Neuroprotection & $\begin{array}{l}\text { May be relevant to } \\
\text { progressive disease and } \\
\text { subpial inflammation }\end{array}$ & $\begin{array}{l}\text { High: based on pathologic } \\
\text { correlations }^{58}\end{array}$ & Unclear & $\begin{array}{l}\text { Clarification on optimal sequence } \\
\text { parameters and prevalence in MS } \\
\text { required }\end{array}$ & $\begin{array}{l}\text { Early, single-center clinical } \\
\text { trials assessing } \\
\text { neuroprotection, } \\
\text { potentially as } \\
\text { a stratification tool }\end{array}$ \\
\hline PET & $\begin{array}{l}\text { Myelin integrity, } \\
\text { microglial/ } \\
\text { astrocytic } \\
\text { activation }\end{array}$ & $\begin{array}{l}\text { Neuroprotection } \\
\text { and repair }\end{array}$ & $\begin{array}{l}\text { Can target specific cells or } \\
\text { pathways; may be useful to } \\
\text { measure repair of acute } \\
\text { lesions in relation to myelin, } \\
\text { microglia, and other } \\
\text { pathologic processes }\end{array}$ & $\begin{array}{l}\text { High, tracers available that } \\
\text { are specific for myelin and } \\
\text { activated microglia }\end{array}$ & $\begin{array}{l}\text { Moderate: change } \\
\text { detectable in small } \\
\text { studies }^{\mathrm{e} 155}\end{array}$ & $\begin{array}{l}\text { Variable tracer availability, } \\
\text { expertise required for } \\
\text { implementation; uses ionizing } \\
\text { radiation; expensive }\end{array}$ & $\begin{array}{l}\text { Early, single-center clinical } \\
\text { trials assessing } \\
\text { neuroprotection and } \\
\text { remyelination }\end{array}$ \\
\hline $\begin{array}{l}\text { Optical } \\
\text { coherence } \\
\text { tomography }\end{array}$ & $\begin{array}{l}\text { Axonal loss } \\
\text { (retina) }\end{array}$ & Neuroprotection & $\begin{array}{l}\text { Ease of implementation, } \\
\text { clinically relevant, practical } \\
\text { sample sizes }\end{array}$ & Moderate: high ${ }^{\mathrm{e} 110}$ & $\mathrm{High}^{53,54, \text { e111 }}$ & $\begin{array}{l}\text { Restriction to the retina, } \\
\text { measurement variability }\end{array}$ & $\begin{array}{l}\text { Phase II clinical trials } \\
\text { assessing } \\
\text { neuroprotection, } \\
\text { screening tool for } \\
\text { remyelinating clinical } \\
\text { trials (select patients with } \\
\text { less axonal loss who may } \\
\text { benefit from repair) }\end{array}$ \\
\hline
\end{tabular}

Abbreviations: MS = multiple sclerosis; MTR = magnetization transfer ratio; QSM = quantitative susceptibility mapping. 
MTR changes have been shown to correlate with histopathologic evidence of demyelination and remyelination. ${ }^{11, \mathrm{e} 18} \mathrm{Al}-$ though sensitive to myelin, the magnitude of magnetization transfer can be affected by edema, inflammation, and axonal density, reducing its specificity. Nonetheless, MTR can be implemented on most clinical scanners, with reasonable acquisition times, high precision, ${ }^{\mathrm{e} 19}$ and simple postacquisition processing algorithms.

The feasibility of measuring dynamic changes in MTR in acute gadolinium-enhancing lesions has been demonstrated. With acute lesion formation, average lesional MTR has been shown to initially decrease, then increase-changes that are partially related to edema but also reflect demyelination followed by partial remyelination. ${ }^{12, \mathrm{e} 20-\mathrm{e} 22}$ In individual lesions, MTR changes correlate with the degree of remyelination and clinical improvement after intervention. ${ }^{13}$ Differential effects on MTR recovery in acute lesions have been demonstrated for specific therapies, suggesting variations in remyelination capacity (figure 1)..$^{14, \mathrm{e} 23}$

Sample sizes for detecting therapeutic effects with MTR are reasonable (table 2). When assessing MTR in individual lesions (which is twice as efficient as averaging MTR across all lesions), an experimental agent with a remyelinating effect size of $30 \%$ could be detected with sample sizes of $20-40$ per study arm. ${ }^{15}$

Challenges of MTR include its sensitivity to acquisition parameters and field strength, pathologic nonspecificity, and nonlinear relationship with myelin density. Approaches to address these limitations have been developed and can be implemented in multicenter clinical trials. ${ }^{16, \text { e24 }}$ MTR remains a promising technique to assess remyelination, and one of the few semi-quantitative myelin measures that has been applied widely in clinical trials. What remains unknown is whether,

Figure 1 Dynamic changes in magnetization transfer ratio (MTR) in an acute multiple sclerosis lesion: Potential utility in assessing novel therapeutics

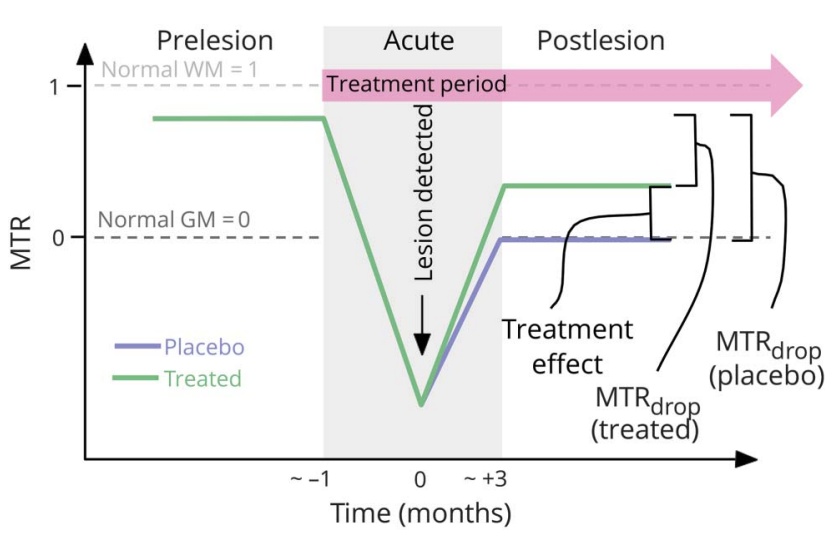

$\mathrm{GM}=$ gray matter; $\mathrm{WM}=$ white matter. Published with permission from Robert Brown. given the dominant contribution of myelin to the WM MRI signal, other approaches with better signal-to-noise characteristics, such as proton density-weighted imaging, could be even more useful, despite their lesser pathologic specificity.

\section{Diffusion tensor imaging (DTI)}

DTI evaluates the 3D diffusion of water molecules in brain tissue (figure 2). ${ }^{17}$ Several DTI-derived measures are sensitive to myelin content, particularly radial diffusivity $(\mathrm{RD})$. $\mathrm{RD}$ captures water diffusion perpendicular to the main direction of diffusion (axial diffusivity) and increases with demyelination. Water molecules are constrained in their diffusion with demyelination along the perpendicular axis and then return to normal with remyelination, as demonstrated in animal models. ${ }^{\text {e25 }}$ Increases in $\mathrm{RD}$ are most apparent in acute MS lesions, ${ }^{17}$ where increases in $\mathrm{RD}$ predict conversion to persistent $\mathrm{T} 1$ hypointensity. $\mathrm{RD}$ also shows measurable recovery after acute lesion formation. Although recovery is variable, stabilization of $\mathrm{RD}$ values is typically seen at 6 months. ${ }^{\text {e2 } 6}$

Although DTI has limited specificity for myelin or axonal integrity, is sensitive to motion, and is cumbersome to analyze, several studies have demonstrated its utility in multicenter settings, ${ }^{18}$ with reasonable scan-rescan reliability across platforms. A recent NAIMS study showed that DTI reliability was high in a single patient with MS scanned at several sites. ${ }^{\text {227 }}$

\section{Repair of chronic WM lesions}

Imaging repair of chronic WM lesions poses several additional challenges compared to acute lesions, as the dynamic range of changes is expected to be small, and pathologic underpinnings of chronic lesions can be complex. Despite these challenges, several MRI measures can be used to target specific pathologic processes within chronic lesions.

\section{Myelin water imaging (MWI)}

Myelin is an obvious target for imaging repair of chronic WM lesions. MWI is a technique that allows imaging of myelin-associated water ${ }^{19}$ and has been validated in chronic WM lesions in postmortem humans ${ }^{\mathrm{e} 28}$ and animals. ${ }^{\mathrm{e} 29} \mathrm{Al}-$ though MWI can also be applied to normal-appearing WM to image neuroprotection and repair, this is not discussed as a separate section due to space constraints.

Chronic lesions show abnormalities in myelin water fraction (MWF) as well as heterogeneity across chronic lesion types, e.g., in relation to $\mathrm{T} 1$ hypointense vs isointense lesions. ${ }^{20}$ Further work is needed to refine our understanding of longterm myelin loss in such lesions. In acute lesions, MWI studies show that the highest rate of myelin recovery occurs within the first months after gadolinium enhancement and that subsequent lesion myelin content is dependent upon the initial MWF values, which reflects both myelin loss and edema. ${ }^{21}$

MWI is potentially an attractive option for clinical trials given its relative specificity to myelin, good intrasite and intersite reliability, ${ }^{22}$ and reproducibility across platforms. 
Table 2 Sample sizes per arm for neuroprotection or repair: proof-of-concept clinical trials

\begin{tabular}{|c|c|c|c|c|c|c|c|}
\hline $\begin{array}{l}\text { Sequence/ } \\
\text { modality }\end{array}$ & Region of Interest & $\begin{array}{l}\text { Effect } \\
\text { size } 20 \%\end{array}$ & $\begin{array}{l}\text { Effect } \\
\text { size } 30 \%\end{array}$ & $\begin{array}{l}\text { Effect } \\
\text { size } 40 \%\end{array}$ & $\begin{array}{l}\text { Effect } \\
\text { size } 50 \%\end{array}$ & $\begin{array}{l}\text { Effect size, } \\
\text { "maximal" } 60 \%{ }^{a}\end{array}$ & Reference \\
\hline \multicolumn{8}{|l|}{ MTR } \\
\hline Gd lesions & Lesions & & 36 & 22 & 14 & & van den Elskamp et al. ${ }^{\mathrm{b}, \mathrm{e} 22}$ \\
\hline Gd lesions & & & 24 & & 12 & & Brown et al. ${ }^{\mathrm{e} 141}$ \\
\hline T2 lesions & & 84 & 38 & 21 & 14 & & Altmann et al. ${ }^{15}$ \\
\hline DTI & \multicolumn{7}{|c|}{ Supratentorial white matter } \\
\hline FA & & & & & 259 & & Harrison et al. ${ }^{\mathrm{e} 156}$ \\
\hline RD & & & & & 105 & & \\
\hline \multirow[t]{2}{*}{ Thalamic volume } & Thalamus & & & & 311 & 109 & Kim et al.., e87 \\
\hline & & & & & & & Azevedo et al. ${ }^{\mathrm{a}, 49}$ \\
\hline Spinal cord CSA & $\mathrm{C} 2 / \mathrm{C} 3$ & & & & & & Cawley et al. ${ }^{\mathrm{e} 157}$ \\
\hline PPMS & & & 157 & & 57 & & \\
\hline SPMS & & & 1538 & & 546 & & \\
\hline Progressive MS & & & 401 & & 146 & & \\
\hline OCT & $\mathrm{GC} / \mathrm{IP}$ & 258 & 119 & 68 & 44 & & Syc et al. ${ }^{\mathrm{d}, \mathrm{e} 113}$ \\
\hline Brain volume & Whole brain & & 140 & & 58 & & Moccia et al. e,e158 \\
\hline PD & New lesions $>15 \mathrm{~mm}^{3}$ & 9 & & & & & Reich et al. ${ }^{\mathrm{f} e 12}$ \\
\hline \multicolumn{8}{|c|}{ 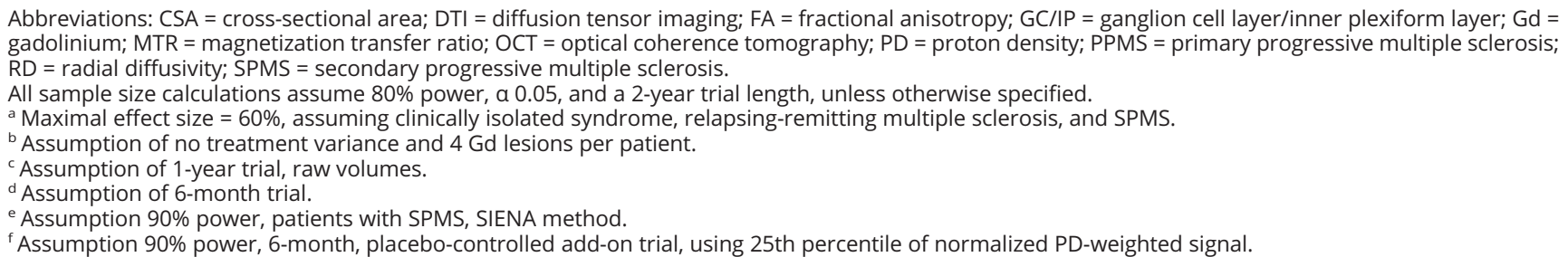 } \\
\hline
\end{tabular}

One historical drawback is the relatively long sequence acquisition times. ${ }^{\text {e30,e31 }}$ Recent advances have allowed for more viable scan times ${ }^{23, \mathrm{e} 31-\mathrm{e} 33}$ at a voxel size sufficient to characterize most chronic lesions, ${ }^{\text {28,e34 }}$ but these newer approaches require histologic validation. Furthermore, MWF is a relative measurement and may be confounded by changes in water content, which can result in a falsely diluted measurement in edematous acute MS lesions. ${ }^{\text {e35 }}$ Approaches have been developed to measure absolute myelin water content using brain CSF as a reference after correcting for the spatial inhomogeneity of $\mathrm{T} 1$, receiver coil sensitivity, and excitation flip angle. ${ }^{24, \mathrm{e} 6}$ MWI may be implemented in studies examining either neuroprotective effects or remyelination in chronic lesions.

\section{Susceptibility-weighted imaging (SWI)}

A second potential target for imaging neuroprotection and repair of chronic lesions involves probing the magnetic susceptibility of tissue. The main contributors to brain parenchymal magnetic susceptibility are diamagnetic myelin and paramagnetic iron. ${ }^{\text {e37 }}$ Quantitative susceptibility mapping (QSM) is a postprocessing technique based on the phase of susceptibility-weighted $\mathrm{MRI}^{25,26, \mathrm{e} 38}$ that enables a direct measure of tissue susceptibility and overcomes the nonlocal problem in $\mathrm{T} 2{ }^{*}$-weighted and phase imaging, though image quality may be slightly compromised. Loss of myelin and deposition of iron both increase the magnetic susceptibility. Many early and intermediate-aged WM lesions (up to 4 years) show increased susceptibility compared to normal-appearing WM, which may, in principle, be due to loss of myelin or iron accumulation. $^{27,28}$ However, pathologic and MRI histology studies have reported iron dispersed throughout individual lesion tissue in only a minority of chronic MS lesions, whereas most MS lesions exhibit central iron loss, ${ }^{29-31, e 39, e 40}$ suggesting that changes in magnetic susceptibility within lesions are mostly due to changes in myelin.

While myelin loss is the main reason for increased magnetic susceptibility of MS lesions, some chronic lesions exhibit a paramagnetic rim on SWI-particularly on phase and QSM images, but often on $\mathrm{T} 2{ }^{*}$-weighted images (and maps) as well (figure 3). ${ }^{31,32, \mathrm{e} 41, \mathrm{e} 42}$ Multiple studies have shown that this 


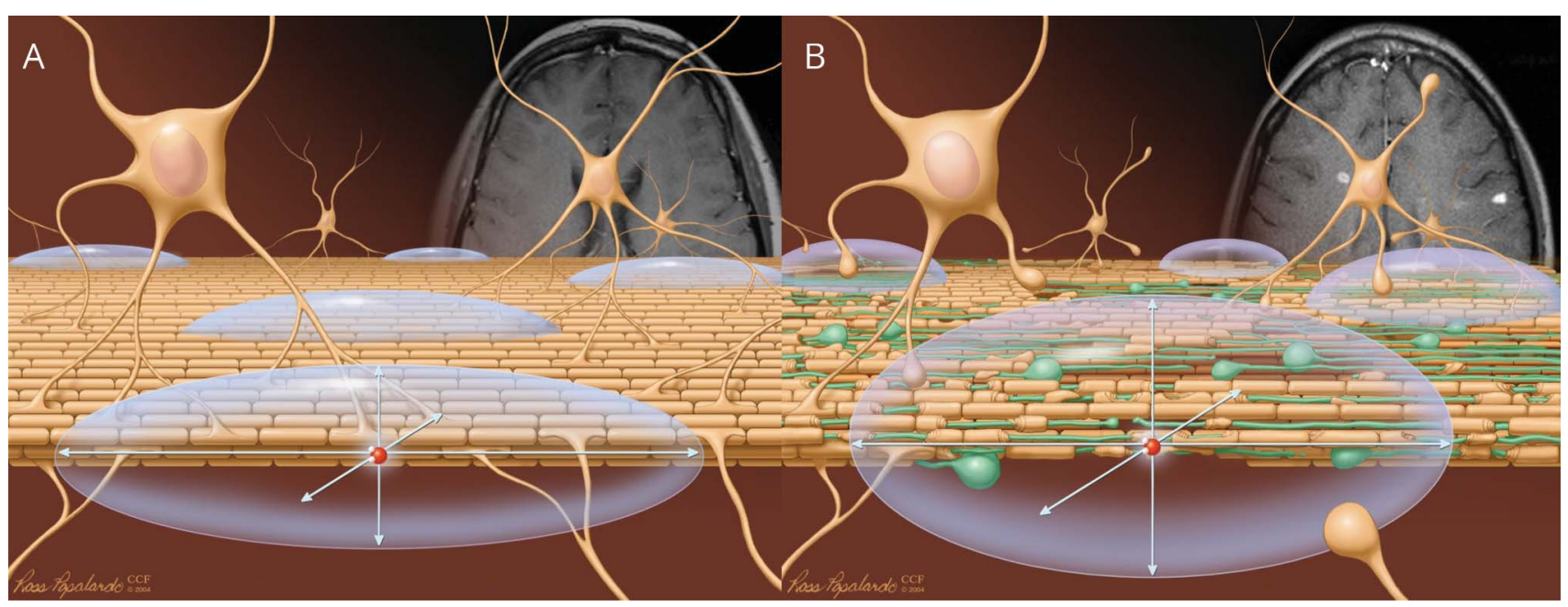

(A) Water diffusion along intact axonal fiber tracts in intact brain tissue. (B) Dispersed water diffusion in brain tissue with demyelination and axonal injury. The arrows indicate the primary, second, and third eigenvectors of the diffusion tensor. Reprinted with permission, Cleveland Clinic Center for Medical Art \& Photography (c) 2004-2018. All Rights Reserved.

rim is due to the presence of iron within phagocytes and is a feature of chronic active (also known as slowly expanding and smoldering) lesions, around which the previously uninvolved WM slowly degenerates. Rims are almost never seen in remyelinated or inactive lesions, ${ }^{31,32}$ though they can be seen in acute lesions, marking the locus of blood-brain barrier leakage. Acute lesions that develop paramagnetic rims by 3 months after onset tend to have less volume decrease and more $\mathrm{T} 1$ hypointensity over the first year. ${ }^{\mathrm{e} 3}$

Considering the above, susceptibility-based imaging and QSM may be useful in proof-of-concept clinical trials

Figure 3 Susceptibility-weighted imaging

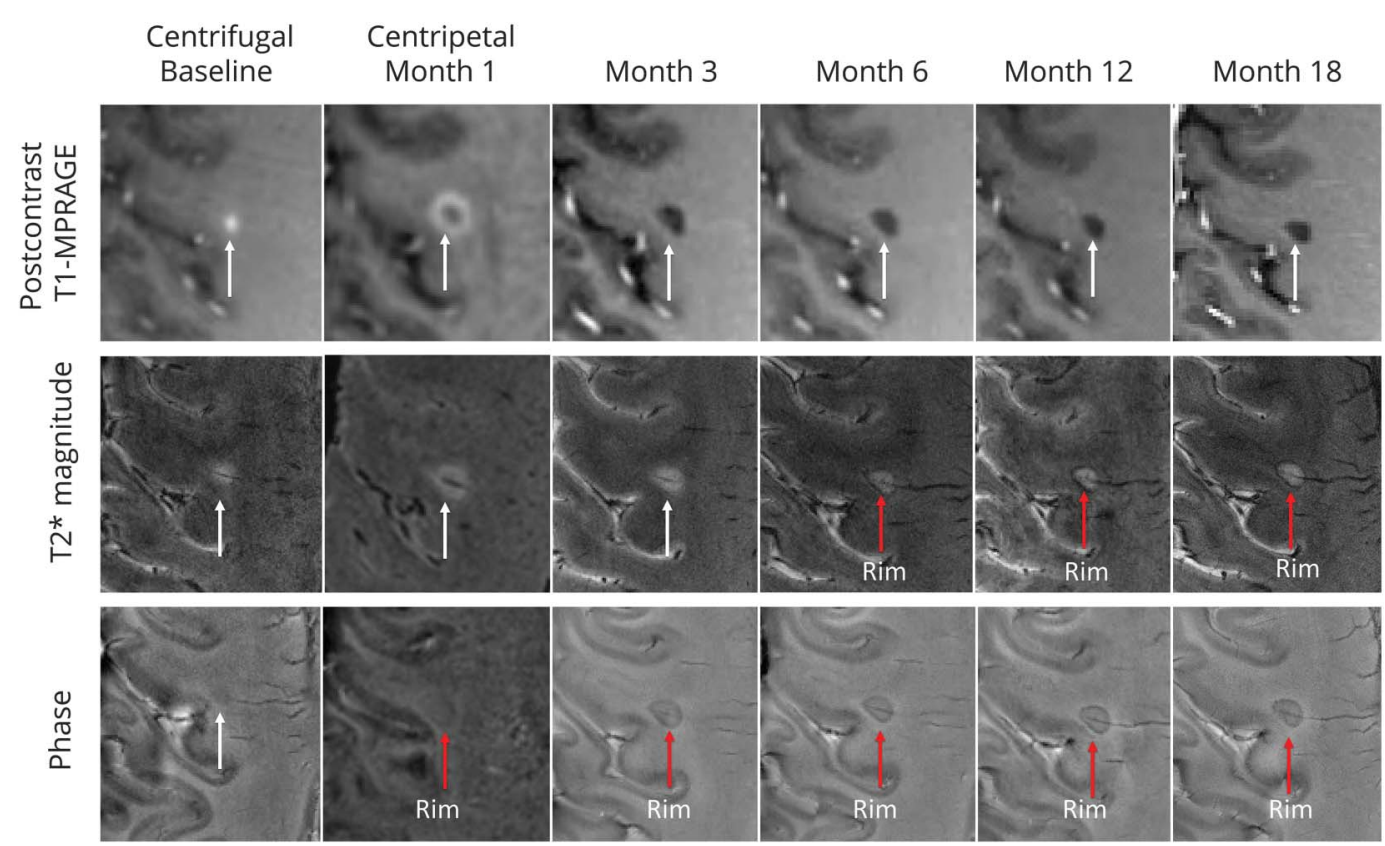

Persistent phase rims in a gadolinium-enhancing lesion in a patient with secondary progressive multiple sclerosis. Postcontrast T1-weighted images demonstrate gadolinium enhancement evolution from centrifugal to centripetal. A hypointense rim can be visualized on noncontrast phase images when the lesion enhances centripetally, and is persistent after enhancement resolution (months 3, 6, 12, 18) and on T2* weighted images (months 6, 12, 18). MPRAGE = magnetization-prepared rapid gradient echo. Reproduced with permission from Absinta M, Sati P, Schindler M, et al. Persistent 7-tesla phase rim predicts poor outcome in new multiple sclerosis patient lesions. J Clin Invest 2016;126:2597-2609. 
assessing both neuroprotection and remyelination. Advantages are high spatial resolution with short data acquisition times, high signal-to-noise ratio, exquisite sensitivity to changes in tissue composition, and wide availability of the scan. Drawbacks include complicated and not-yet-standardized data processing, which requires the exclusion of paramagnetic central veins, ${ }^{\mathrm{e} 44}$ as well as the need for careful and nuanced interpretation.

\section{PET imaging}

PET allows directly imaging pathologic substrates of chronic lesions. ${ }^{11} \mathrm{C}-\mathrm{MeDAS} \quad\left(\mathrm{N}-\left[{ }^{11} \mathrm{C}\right]\right.$ methyl-4,4'-diaminostilbene), studied in animals, is sensitive to both demyelination and remyelination. ${ }^{33}$ Another tracer, Pittsburgh compound B ([methyl- $\left.{ }^{11} \mathrm{C}\right]-2-\left[4^{\prime}\right.$-methylaminophenyl $]-6-$ hydroxybenzothiazole), has demonstrated sensitivity for myelin in animal studies ${ }^{34}$ and changes in chronic MS lesions in humans, potentially identifying remyelination. ${ }^{\text {e45 }}$

Several PET tracers have been developed to image activated microglia. The translocator protein (TSPO), a mitochondrial membrane cholesterol transporter, is a putative biomarker for activated microglia. The most frequently used pharmaceutical tracer has been $\left[{ }^{11} \mathrm{C}\right]-(\mathrm{R})-\mathrm{PK} 11195$, which shows a rim pattern colocalizing with activated microglia in chronic active lesions. ${ }^{35}$ However, specificity for activated microglia is not complete, as PK11195 also binds to reactive astrocytes. Second-generation TSPO ligands include over 50 different potential compounds, including ${ }^{11} \mathrm{C}$-PBR28, ${ }^{18} \mathrm{~F}$-PBR111, and ${ }^{18}$ F-DPA714. The use of second-generation TSPO radioligands may be limited in clinical trials as genetic polymorphisms affecting binder affinity are frequent. ${ }^{\text {e46 }}$

Overall, PET is a promising technology for measuring repair of acute lesions in relation to myelin, microglia, and other pathologic processes. Lack of widespread tracer availability, expertise required for implementation, high expense, low spatial resolution, and radiation exposure (especially with repeat dosing) remain barriers to implementation in multicenter clinical trials. In the future, PET, or PET/MRI, may be useful for experimental therapeutics targeting specific cells or pathways.

\section{Repair of cortical lesions}

Cortical lesions are a key component of MS pathology and a significant correlate of neurologic disability. ${ }^{36, \mathrm{e} 47, \mathrm{e} 48}$ Cortical lesions can be divided into 3 major types ${ }^{\text {e48 }}$ : leukocortical, intracortical, and subpial.

The relatively low myelin content in the cortex has limited the ability to visually detect cortical lesions at standard field strengths. Voxel-wise or vertex-wise analyses of cortical myelin integrity can overcome some of the limitations of visual cortical lesion-based analyses. ${ }^{37, e 49-5155}$ A series of semi-quantitative (MTR, DTI, diffusion kurtosis, T1-weighted/T2-weighted ratio) and quantitative (T2, T2* $\mathrm{T} 1)$ magnetic resonance (MR) contrasts can be used, $^{37, \mathrm{e} 52,53}$ as well as myelin-sensitive PET radiotracers. ${ }^{34}$ As for WM lesions, no imaging quantity is entirely myelin-specific.

At clinical field strengths, dedicated MRI sequences such as double inversion recovery and phase sensitive inversion recovery can detect cortical lesions in all stages of MS. ${ }^{38, e 54,55}$ The sensitivity of these protocols to subpial demyelination, however, remain limited. $7 \mathrm{~T}$ MRI greatly increases detection of cortical MS lesions, ${ }^{39}$ but this is dependent on cortical lesion type, with $\mathrm{T} 22^{*}$-weighted MRI providing a relative benefit compared to other contrasts in detecting subpial lesions. ${ }^{40}$ In histopathologic-MRI correlative studies, sensitivities for 7T T2*-weighted MRI to cortical lesions vary from $\sim 35 \%-47 \%$ (prospective) to $\sim 63 \%-93 \%$ (retrospective), ${ }^{39, \mathrm{e} 42,56}$ suggesting a need for optimization and standardization of acquisition and evaluation procedures.

Statistical models combining MR contrasts can increase specificity to different aspects of cortical pathology. A recent multivariate model using different $\mathrm{MR}$ contrasts to account for confounding factors (iron, B0, cortical thickness) estimated myelin distribution in the cortex from quantitative $\mathrm{T} 2{ }^{*}$ at $7 \mathrm{~T}$ and MTR at $3 \mathrm{~T}^{41}$ Myelin estimation obtained with this model showed similar trends to histopathology. ${ }^{41}$

With further validation, techniques that detect cortical lesions or evaluate cortical myelin could be useful as measures of neuroprotection or repair in proof-of-concept studies. Furthermore, PET-based assessment of cortical microglial activation could provide information to stage cortical lesions and stratify patients based on their remyelination potential. ${ }^{\mathrm{e} 57, \mathrm{e} 58}$

A number of limitations preclude widespread use of these measures, including the small size of cortical lesions and complex cortical geometry. $7 \mathrm{~T}$ imaging remains the most sensitive platform for cortical lesion detection, but the technology is only now starting to gain wide availability.

\section{Repair of energy deficits}

Predictors of brain tissue loss may ultimately become the target of the next generation of DMTs, with the goal of identifying the underlying biology leading to, and tissue at risk for, neurodegeneration. Several brain metabolites measured with MR spectroscopy (MRS) may have promise as upstream predictors and can provide insights into cellular energy metabolism, mitochondrial function, or oxidative stress.

Previous studies have demonstrated that mitochondrial energy failure leading to oxidative stress plays a central role in MS-related axonal degeneration, preceding structural brain atrophy. ${ }^{\text {e59 }}{ }^{1} \mathrm{H}-\mathrm{MRS}$ metabolites reflecting cellular energy status in MS include $\mathrm{N}$-acetylaspartate (NAA), creatinine/ phosphocreatine, and glutathione. ${ }^{60}$ NAA is interpreted as a marker of neuroaxonal integrity reflecting both structural density and mitochondrial function. ${ }^{42, \mathrm{e} 61}$ Decreased NAA is seen in acute and chronic MS lesions and in normal-appearing WM, and may precede brain atrophy. ${ }^{42, \mathrm{e} 61-\mathrm{e} 65}$ 
Recent MRS research has focused on glutamate and glutathione dysregulation. During acute MS injury, activated macrophages/microglia release glutamate into the extracellular compartment, ${ }^{\text {e66 }}$ where there is defective glutamate uptake by oligodendrocytes. ${ }^{\text {667 }}$ This initiates an oxidative cascade $^{\mathrm{e} 68, \mathrm{e} 69}$ leading to the overproduction of reactive oxygen species, neuronal mitochondrial dysfunction, ${ }^{\text {e70-e72 }}$ reduced adenosine triphosphate (ATP), and ionic imbalance. Glutathione is an antioxidant essential for protecting against reactive oxygen species. In vivo ${ }^{1} \mathrm{H}-\mathrm{MRS}$ imaging has demonstrated a reduction of glutathione in the gray matter (GM) and focal lesions, ${ }^{43, \mathrm{e} 73}$ suggesting that patients with MS may lack the ability to produce sufficient glutathione in the presence of a glutamate stimulus.

As a direct measure of high-energy phosphates (ATP and phosphocreatine), phosphorus $\left({ }^{31} \mathrm{P}\right)$-MRS may provide additional insight into energy metabolism in MS. Using single-voxel ${ }^{31} \mathrm{P}$-MRS imaging at $7 \mathrm{~T}$, combined with ${ }^{1} \mathrm{H}$ MRS, high-energy phosphates can be reduced in GM, ${ }^{44}$ which may predict brain atrophy. In addition, dynamic contrast techniques such as brain capillary water lifetime are under development to measure cellular water cotransport, which is proportional to plasma membrane P-type ATPase turnover and may offer additional insight into cellular energy metabolism. ${ }^{\text {e74,e75 }}$ Although still in early phases of investigation, this technique could eventually complement established MRS methods and offer high spatial resolution maps of brain metabolic activity.

At present, these metabolic markers might be most useful to probe biological mechanisms in the context of proof-ofconcept clinical trials. Several technical challenges limit their utility as primary endpoints for multicenter clinical trials, including low spatial resolution as well as variability in metabolite quantification across scanners.

\section{Repair and neuroprotection of axons at risk}

Axonal integrity can be preserved by enhancing remyelination or promoting neuroprotection. This section discusses emerging techniques to quantify axonal density that have mainly been applied within MS lesions.

\section{Advanced diffusion imaging}

Several advanced diffusion MRI techniques can quantitatively assess axon density with improved specificity to tissue microstructure changes. DTI's specificity for axon integrity is diminished in the presence of acute inflammation and chronic tissue loss. ${ }^{\text {e76 }}$ A number of more complex compartmentspecific models attempt to address this limitation by accounting for intra-axonal, extra-axonal, and free water diffusion. ${ }^{45}$

Diffusion basis spectrum imaging aims to evaluate the anisotropic component of diffusion, to account for cellularity and extracellular space. ${ }^{\text {e77 }}$ Other approaches such as AxCaliber and ActiveAx can additionally provide information on axon diameter but may require high gradient MR systems to provide robust data. ${ }^{\mathrm{e} 78, \mathrm{e} 79}$ Models such as neurite orientation dispersion and density imaging (NODDI) provide information on axon density and variation of fiber orientation with improved clinical feasibility. ${ }^{\mathrm{e} 80}$

In the corpus callosum, AxCaliber has been applied in MS to demonstrate increased axon diameter and decreased axonal density within lesions. ${ }^{\text {e79 }}$ NODDI can also detect decreased axon density and increased orientation dispersion in lesions. ${ }^{\text {e80 }}$ In the setting of axonal loss, techniques such as AxCaliber may provide useful information regarding axon diameter distribution that could identify the size of axons at greatest risk of damage and dropout.

These advanced diffusion techniques may be of utility as measures of neuroprotection in single-center trial settings. Limitations include that many of these diffusion models are insensitive at probing small-diameter axons using conventional magnetic field gradients ${ }^{\mathrm{e} 81}$ and the need for pathologic correlational studies. While high-gradient-strength MR systems are becoming more prevalent, limited availability currently makes multicenter application a challenge.

\section{Sodium imaging}

${ }^{23} \mathrm{Na}$ MRI quantifies the tissue total sodium concentration (TSC), representing the weighted average of intracellular and extracellular ${ }^{23} \mathrm{Na}$. Intra-axonal accumulation of ${ }^{23} \mathrm{Na}$ ions, determined by $\mathrm{Na} / \mathrm{K}$ pump dysfunction, increases TSC. ${ }^{46}$ While TSC increase in chronic lesions might be explained by gliosis, tissue disruption, and replacement with extracellular fluid, TSC increase in nonchronic lesions and normalappearing brain tissue is related not only to increased extracellular space, but also to the increase of intracellular sodium concentration (ISC).

In patients with MS, ISC increase may reflect axonal dysfunction, offering insights into axonal metabolism before the generation of stable, irreversible, axonal damage. Since ISC accumulation is a reversible phenomenon occurring spontaneously in a number of neurons in physiologic conditions, it could be a putative target for therapeutic interventions, providing a better tool to investigate the neuroprotective effects of experimental therapies in early, proof-of-concept clinical trials. ${ }^{\mathrm{e} 2}$

One notable limitation of sodium imaging technique is its low spatial resolution. This is somewhat improved by increasing field strength to $7 \mathrm{~T}$, with inherent challenges to multicenter application.

\section{Multimodal approaches}

Since myelin and axonal integrity influence one another, any study design assessing for improvement in myelin content may consider including a measure of axonal content (to select patients most likely to respond to remyelinating therapies) and vice versa. Multimodal approaches that incorporate information about the integrity of both, such as in vivo g-ratio estimation (defined as the ratio between the inner and the 
outer diameter of the myelin sheath), could also prove useful, if validated. ${ }^{\text {e83,e84 }}$

\section{Repair and neuroprotection of special regions}

\section{Deep GM}

The deep GM nuclei are affected by several aspects of the MS disease process. ${ }^{\text {e85 }}$ Although a number of deep GM structures are highly relevant, ${ }^{\mathrm{e} 86, \mathrm{e} 87}$ we focus here on the thalamus as a region of particular interest.

Recent literature suggests that thalamic volume is a promising MRI measure of neurodegeneration, and potentially useful as a primary endpoint in phase II clinical trials. As a major relay center, the thalamus is involved in a wide range of neurologic functions and may be particularly vulnerable to upstream or downstream neurodegeneration due to axonal transection within WM lesions. ${ }^{\text {e8 }}$ Axonal transection is likely a major contributor to the reduction in thalamic volume seen histopathologically, ${ }^{\mathrm{e} 9}$ but iron deposition ${ }^{\mathrm{e} 55}$ and demyelinating lesions ${ }^{47,48}$ may also contribute. ${ }^{\mathrm{e} 41, \mathrm{e} 90, \mathrm{e} 91}$ Thalamic volume measurements by MRI likely reflect the net effects of these processes, and hence can be considered a barometer for overall tissue damage in MS. ${ }^{48, e 92}$

The presence of thalamic atrophy on MRI has been reported cross-sectionally in early phases of demyelinating disease, including CIS, ${ }^{49, \mathrm{e} 93}$ pediatric MS, ${ }^{\mathrm{e} 94}$ and radiologically isolated syndrome. ${ }^{\text {e95 }}$ Thalamic volume correlates well with physical $^{\text {e90 }}$ and cognitive disability. ${ }^{\text {e96 }}$ Importantly, the rate of thalamic volume decline has been shown to be consistent throughout the MS disease duration, and sample-size calculations incorporating normal aging have yielded practical estimates for phase II clinical trials (table 2). ${ }^{49, e 87}$ Emerging post hoc and prespecified clinical trial data suggest that thalamic atrophy is modifiable with DMT. ${ }^{49, \mathrm{e} 97}$

Thalamic volume is a promising endpoint associated with neurodegenerative aspects of MS, making it a potentially useful measure of neuroprotection in phase II clinical trials. One limitation is that it is a small structure not well-defined on conventional images, which can lead to high measurement variability.

\section{Hippocampus}

The hippocampus is a complex GM structure situated within the mesial temporal lobe with several subregions of differing histology, functional specificity, and susceptibility to disease processes in MS. ${ }^{\text {e98,e99 }}$ The hippocampus forms the neuroanatomical foundation for declarative memory functions and is also implicated in emotional responses and mood regulation.

The hippocampus is a frequent target of disease effects in MS, as shown by structural and functional imaging ${ }^{50,51, \mathrm{e} 100-\mathrm{e} 103}$ and neuropathologic studies. ${ }^{\text {e104-e106 }}$ Widespread demyelination, neuronal loss, and diminished dendritic density may be

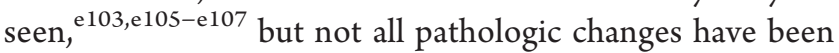
tied directly to inflammatory activity. ${ }^{\text {e104,e105,e107,e108 }}$ MRI can detect hippocampal atrophy in early stages of relapsing- remitting MS (RRMS), affecting the CAl subregion preferentially and associated with deficits in verbal memory. ${ }^{\text {e102 }}$ Depression and altered cortisol secretion patterns in RRMS are associated with additional hippocampal changes, including in subregion CA3. ${ }^{\mathrm{e} 102, \mathrm{e} 108, \mathrm{e} 109}$

Several hippocampal MRI measures could be sensitive and specific primary endpoints for studies focused on memory impairment and depression, making it relevant to neuroprotection and repair. Although not yet validated for use in clinical trials, hippocampal atrophy, surface-based topology, subregional changes, and connectivity are currently under study. Future work should focus on longitudinal changes in these measures, their relationship to clinical endpoints, and the effect of neuroprotective treatments.

\section{Retina}

Optical coherence tomography (OCT) is a noninvasive, inexpensive, and reproducible imaging technique that generates high-resolution images of the retina, allowing most individual layers to be quantified. In MS, pathologic studies have shown that $\sim 80 \%$ of cases demonstrate ganglion cell layer nuclear dropout, and $40 \%$ had inner nuclear layer (amacrine and bipolar cell) loss. ${ }^{\text {e110 }}$

Reductions in OCT-derived peripapillary retinal nerve fiber layer thickness ( $\mathrm{pRNFL}$ ) and ganglion cell + inner plexiform layer (GCIP) thickness are observed in patients with MS with and without a history of optic neuritis. ${ }^{52}$ GCIP thickness has demonstrated superior reliability and reproducibility and correlates better with visual function and disability in MS than pRNFL. ${ }^{\text {e110 }}$ Rates of GCIP thinning are accelerated in patients with MS exhibiting inflammatory activity, correlate strongly with rates of whole-brain and GM atrophy over time, and are modulated by DMTs. ${ }^{53, \mathrm{e} 111}$ Longitudinal studies of 5- and 10year follow-up periods show that baseline OCT predicts changes in Expanded Disability Status Scale. ${ }^{54}$

There are several different spectral-domain OCT scanners in use, and cross-platform comparison of data remains an issue. On the other hand, retinal segmentation algorithms that can perform longitudinal analyses of data acquired on the same scanner allow an assessment of individual rates of change over time, which can be compared across scanners. ${ }^{\text {e112 }}$

Given the ease of implementation, OCT-derived metrics could be useful as an outcome measure in phase II neuroprotection trials. Sample size calculations to detect a $50 \%$ reduction in GCIP thinning following acute optic neuritis are reasonable (44-59 subjects per arm, table 2). ${ }^{\text {e113 }}$ While achieving neuroprotection is a great need in progressive MS, establishing efficacy with OCT may be more challenging, as the annual rate of change is less than in RRMS. Another potential application of OCT is as a screening tool for remyelinating clinical trials to select patients with less axonal loss who may therefore have the potential to respond to a remyelinating therapy. 
Figure 4 Quantitative spinal cord MRI measures

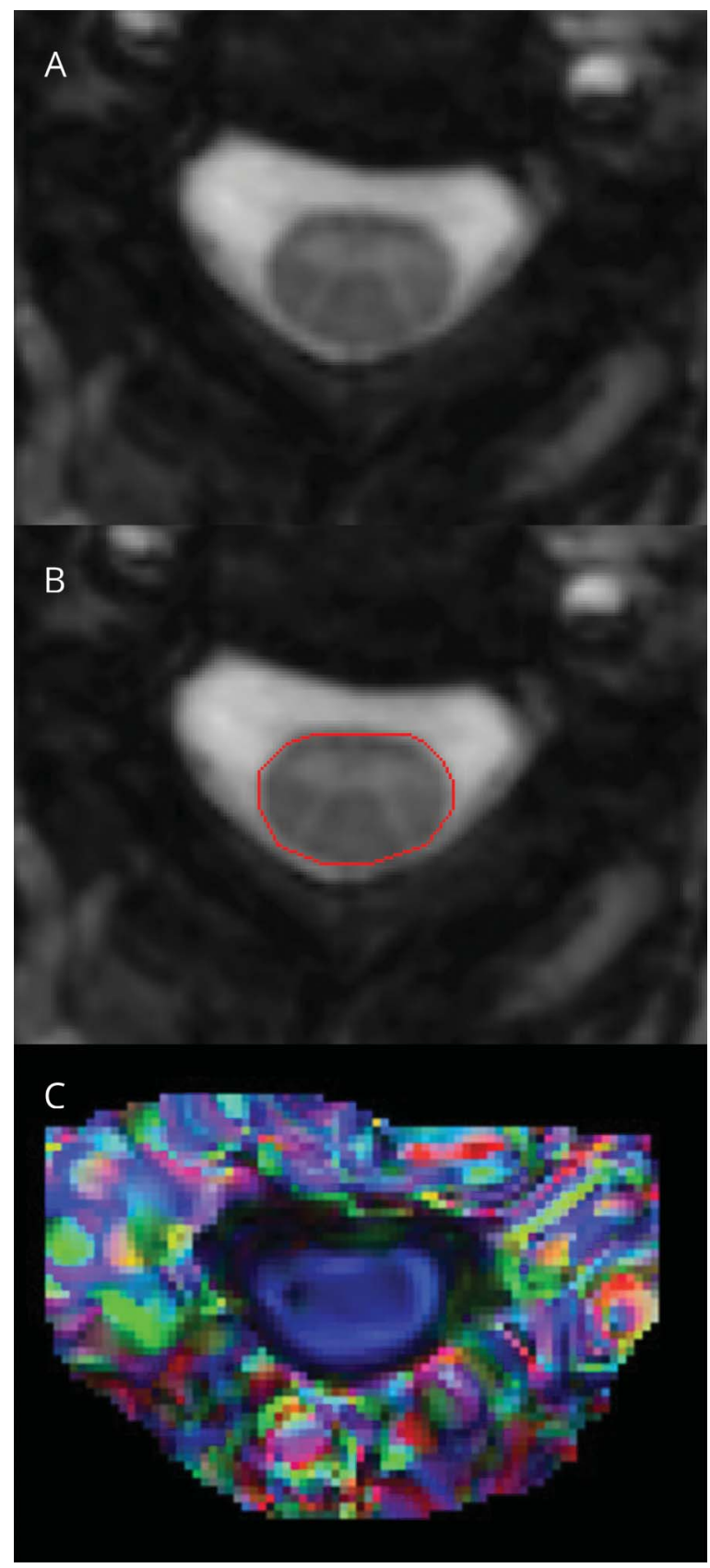

(A, B) Automated segmentation of spinal cord cross-sectional area. (C) Colorcoded diffusion tensor imaging map (derived from fractional anisotropy and the principal eigenvector) demonstrates spinal cord fibers running along the rostrocaudal axis (blue). Reproduced with permission from Oh J, Sotirchos ES, Saidha S, et al. Relationships between quantitative spinal cord MRI and retinal layers in multiple sclerosis. Neurology 2015;84:720-728.

Limitations of OCT include its restriction to the retina and that annual changes at the cohort level $(0.5-1.5 \mu \mathrm{m})$ are less than individual variability in scanner reproducibility $(2-4 \mu \mathrm{m})$.

\section{Spinal cord (SC)}

\section{Conventional SC measures}

The SC is a compact structure organized into functional columns. It is frequently affected in all stages of $\mathrm{MS}^{\mathrm{e} 114}$ and contributes substantially to disability. As such, it is a useful structure to assess neuroprotective and repair mechanisms of candidate drugs.

Clinical imaging of the SC has mostly been geared toward lesion detection, ${ }^{\mathrm{e} 14}$ and clinical correlations with SC lesion count and volume in patients with MS have been limited. $^{\text {e114-e116 }}$ Although SC lesions can theoretically assess repair in a similar manner to acute brain lesions, technical difficulties with SC lesion detection using conventional sequences limits the utility of this approach. Recent advances in MRI sequences may make it possible to utilize the development and evolution of acute lesions in the SC to measure neuroprotection and repair in the future. ${ }^{\text {e117 }}$

\section{SC atrophy}

The most commonly utilized quantitative SC measure has been assessing atrophy via the upper SC cross-sectional area (figure 4). Strong correlations have been demonstrated with clinical disability, across all stages of MS. ${ }^{55, \mathrm{e} 118}$ Furthermore, rates of SC atrophy have been reported to be up to $2 \%$ per year and are accelerated in progressive MS, making this measure a potential candidate to assess neuroprotection and even repair. ${ }^{\text {e119 }}$ The greatest limitation preventing widespread use of SC atrophy is measurement variability. Recent studies have identified that SC GM atrophy often occurs in early RRMS, prior to the onset of general atrophy. ${ }^{56}$ However, this measure can be difficult to obtain in the presence of focal SC lesions. Further validation and refinement of methods to measure SC GM may eventually make this an attractive measure of neuroprotection for experimental drugs in early trial settings, particularly for progressive MS. ${ }^{\text {119 }}$

\section{Advanced SC imaging}

More advanced imaging techniques have been applied to the SC in MS, including DTI, MTI (figure 4), MWI, and fMRI. ${ }^{57, e 120-e 122}$ Most of these techniques have benefits over conventional techniques as they can quantify underlying tissue changes and have demonstrated robust correlations with clinical disability. However, measurement variability and complexity of image analysis limit their practical use in detecting neuroprotection or repair in clinical trials.

\section{Leptomeninges}

Interest in the leptomeningeal compartment has increased in recent years, as accumulating evidence confirms the importance of leptomeningeal inflammation and colocalizing subpial demyelination in mediating disability in all stages of MS. $^{\text {e123 }}$

Leptomeningeal inflammation has been difficult to visualize with conventional techniques, but recent studies have reported the presence of leptomeningeal enhancement (LME) in MS on T2-fluid-attenuated inversion recovery (FLAIR) MRI performed at least 10 minutes after IV gadolinium administration. In one study, LME was observed with a prevalence of $25 \%$ in a cohort of patients with relapsing and progressive MS; 
prevalence was highest in those with primary progressive MS $(\sim 40 \%)$ and correlated with disability scores. ${ }^{58}$ The pathologic correlate of LME was explored in 2 autopsy cases that localized LME with inflammatory cell aggregates around meningeal vessels in close proximity to subpial cortical demyelination. More recent studies using modifications of the FLAIR technique (subtraction imaging, 7T) report an even higher prevalence of LME (50\%-90\%) $)^{\mathrm{e} 124}$ and an association of LME with more rapid GM atrophy at 5 years. ${ }^{59}$

LME imaging is in early stages of development and requires clarification on prevalence, optimal acquisition technique, and treatment responsiveness. Morphologically similar LME is also prevalent in other neuroinflammatory diseases. ${ }^{\text {e125 }}$ If validated to be relevant to progressive disease initiation and propagation in MS, the presence/absence of LME may emerge as a measure to monitor candidate drugs with neuroprotective effects.

\section{Study design and statistical considerations}

Although imaging measures of neuroprotection can sometimes be used to measure repair, important study design considerations may differ between these 2 categories. Measuring neuroprotection requires an appropriate comparator group, because it would otherwise be difficult to demonstrate tissue loss that did not occur in an individual or group of patients. Repair may be more absolute with imaging methods targeting the re-emergence of tissue that was previously damaged (figure 1).

Another study design consideration for many of the techniques discussed is that it may be useful to make the unit of observation an MS lesion, rather than an individual patient. This has substantial implications for sample size and power calculations but must be done with caution, since imaging features in different lesions within the same individuals are likely to be correlated.

Intersite and scanner variability in MRI-derived metrics remain a major issue in multicenter studies. ${ }^{\text {e126-e133 }}$ Statistical techniques such as mixed-effects models applied to extracted biomarkers have traditionally been used to address this problem, but these approaches do not completely take into account all sources of variability, particularly when multimodal techniques are used. More advanced statistical techniques, including corrections applied directly on images or to panels of radiomic features, may allow a more comprehensive accounting of sources of variability, and techniques used will have to be tailored to specific quantitative MRI techniques. ${ }^{9,60, \mathrm{e} 134-\mathrm{e} 139}$ Furthermore, variability related to segmentation and registration methodology must be considered when uniform processing methods are applied across sites. ${ }^{10, \mathrm{e} 140}$

Longitudinal, multimodal MRI (conventional and advanced) of acute WM lesions presents an opportunity to extract both temporally and spatially consistent information that reflects tissue damage and repair. By integrating intensity patterns before, at, and after lesion formation, and modeling trajectories using advanced statistical approaches, ${ }^{\text {e141-e146 }}$ new biomarkers that are more correlated to disease-related changes and therapeutic effects may be developed. In the future, by leveraging changes in the local intermodality covariance structure, ${ }^{8, \mathrm{e} 147}$ these measures may be able to disentangle demyelinating changes, repair process, and imaging artifacts, providing more sensitive and specific markers for therapeutic trials.

\section{Discussion}

Imaging biomarkers of neuroprotection and repair are needed to accelerate the discovery of effective treatments for all stages of MS. Based on the collective opinion of the NAIMS Cooperative, it is evident there are a number of promising techniques with different strengths and limitations. Selection of a specific technique will depend on a number of factors, including clinical setting, outcome being targeted, study design, mechanisms of action of candidate drugs, patient population, and resources. Advanced statistical methods can be applied to different techniques in multicenter settings to account for variability and to extract important information that may be useful to model neuroprotection and repair. Ongoing collaborative efforts will enable further refinement and improved methods to image the effects of novel therapeutic agents in MS predominately through neuroprotective and reparative mechanisms.

\section{Author contributions}

Drs. Oh, Reich, Sicotte, Ontaneda, Azevedo, Klawiter, and Reich contributed to the study concept and design, acquisition of data, analysis and interpretation, critical revision of the manuscript for important intellectual content, and study supervision. Drs. Absinta, Arnold, Bakshi, Calabresi, Crainiceanu, Dewey, Freeman, Gauthier, Henry, Inglese, Kolind, Li, Mainero, Menon, Nair, Narayanan, Nelson, Pelletier, Rauscher, Rooney, Sati, Schwartz, Shinohara, Tagge, Traboulsee, Wang, Yoo, Yousry, and Zhang contributed to the acquisition of data, analysis and interpretation, and critical revision of the manuscript for important intellectual content.

\section{Study funding}

The NAIMS workshop was hosted with support from the Race to Erase MS Foundation and EMD Serono Canada.

\section{Disclosure}

J. Oh has received research grant funding from the MS Society of Canada, National Multiple Sclerosis Society (NMSS), Brain Canada, Biogen-Idec, and Sanofi-Genzyme; and has received personal compensation for consulting or speaking from EMD Serono, Sanofi-Genzyme, Biogen-Idec, Novartis, and Roche. D. Ontaneda has received research grant funding from the NMSS, $\mathrm{NIH}$, Patient-Centered Research Institute, Race to Erase MS Foundation, Genentech, and Genzyme; and has received 
personal compensation for consulting from Biogen Idec, Genentech/Roche, Genzyme, and Merck. C. Azevedo has received personal compensation for consulting from Genentech, Genzyme, and Guerbet. E. Klawiter has received research grant funding from Atlas5D, Biogen, EMD Serono, and Roche, as well as personal compensation for consulting from Acorda, Atlas5D, Biogen, EMD Serono, Genentech, and Shire. M. Absinta has received grant funding from the NMSS and the Conrad N. Hilton Foundation. D. Arnold has received research grant funding and/ or personal compensation for consulting from Acorda, Adelphi, Alkermes, Biogen, Celgene, Frequency Therapeutics, Genentech, Genzyme, Hoffman-La Roche, Immuene Tolerance Network, Immunotec, MedDay, EMD Serono, Novartis, Pfizer, Receptos, Roche, Sanofi-Aventis, Canadian Institutes of Health Research, MS Society of Canada, and International Progressive MS Alliance; and holds an equity interest in NeuroRx Research. R. Bakshi has received research grant funding from EMD Serono and Sanofi-Genzyme, as well as personal compensation for consulting from Bayer, EMD Serono, Genentech, Guerbet, Sanofi-Genzyme, and Shire. P. Calabresi has received research grant funding from Annexon, MedImmune, Biogen, Sanofi, and Novartis, as well as personal compensation for consulting from Biogen and Disarm Therapeutics. C. Crainiceanu, B. Dewey, and L. Freeman report no disclosures relevant to the manuscript. S. Gauthier has received research grant funding from Mallinckrodt, Genzyme, and Novartis. R. Henry has received research grant funding from Genentech, MedDay, and Sanofi-Genzyme; and has received personal compensation for consulting from Hoffman-La Roche, Novartis, MedDay, AbbVie, and Questcor, as well as educational support from Teva and Genzyme. M. Inglese has received research grants from NIH, NMSS, DOD, and Teva Neuroscience. S. Kolind has received research grant funding from Hoffmann-La Roche and Sanofi-Genzyme. D. Li has received research funding from the Canadian Institute of Health Research and Multiple Sclerosis Society of Canada and has received consulting fees from Biogen-Idec, EMD Serono, Genzyme, Novartis, Nuron Biotech, Opexa, and Vertex Pharmaceuticals C. Mainero reports no disclosures relevant to the manuscript. $\mathrm{R}$. Menon has received research grant funding from the Canadian Institutes of Health Research Foundation, Natural Science and Engineering Research Council of Canada, Brain Canada, and Siemens Healthineers; and sold a patent to Siemens Healthcare. G. Nair and S. Narayanan report no disclosures relevant to the manuscript. F. Nelson has received research grant funding from Alkermes, Novartis, and the NMSS, as well as personal compensation for speaking or consulting from Acorda, Bayer, Consortium of Multiple Sclerosis Centers, Genentech, Novartis, Sanofi-Genzyme, and Teva. D. Pelletier has served on scientific advisory boards for Biogen, EMD Serono, Genzyme/Sanofi Aventis, Hoffman-La Roche, and Novartis; has received research support for Biogen, Genzyme, Hoffman-La Roche, and the National Institute of Neurologic Disorders and Stroke of the NIH; and has received honoraria for providing consulting services at scientific advisory board meetings from Biogen, EMD Serono, Genzyme/Sanofi Aventis, Hoffman-La Roche, and Novartis. A. Rauscher has received personal compensation for speaking from Philips Medical and served on a scientific advisory board for
Hoffmann-La Roche. W. Rooney has received salary support from the NIH, Conrad N. Hilton Foundation, Paul G. Allen Family Foundation, and Department of Defense, as well as personal compensation for consulting from Biogen and Teva. P. Sati and D. Schwartz report no disclosures relevant to the manuscript. R. Shinohara has received personal compensation for consulting and has served on a scientific advisory board for Genentech/ Roche. I. Tagge reports no disclosures relevant to the manuscript. A. Traboulsee has received research grant funding from Chugai, Roche, Novartis, Genzyme, and Biogen, as well as personal compensation for consulting or speaking from Genzyme, Roche, Teva, Biogen, and EMD Serono. Y. Wang owns equity in Medimagemetric LLC. Y. Yoo has received educational grant funding and support to attend conferences from the MS Society of Canada. T. Yousry has received research grant funding from the Medical Research Council, MS Society of Great Britain and Northern Ireland, Stroke Association, British Heart Foundation, Wellcome Trust, GlaxoSmithKline, Biogen Idec, Novartis, Merck, and MS Society of Australia; and has received personal compensation for consulting from Biogen Idec and Ixico Technologies Ltd., as well as travel support from the European Society of Radiology and Hikma. Y. Zhang has received research grant funding from the MS Society of Canada, Natural Sciences and Engineering Council of Canada, and Alberta Innovates. N. Sicotte has received research grant funding from the NMSS, Guthy-Jackson Charitable Foundation, and Patient-Centered Outcomes Research Institute. D. Reich has received personal compensation and/or nonfinancial support for speaking or consulting from Leventhal \& Puga, LLC and At the Limits; and has a patent system and method of automatically detecting tissue abnormalities (US Patent 9607392) issued, and a patent method of analyzing multi-sequence MRI data for analyzing brain abnormalities in a subject (US20150045651A1) pending. Go to Neurology.org/N for full disclosures.

\section{Publication history}

Received by Neurology June 5, 2018. Accepted in final form November 29, 2018

\section{References}

1. Barkhof F, Calabresi PA, Miller DH, Reingold SC. Imaging outcomes for neuroprotection and repair in multiple sclerosis trials. Nat Rev Neurol 2009;5:256-266.

2. Oh J, Bakshi R, Calabresi PA, et al. The NAIMS cooperative pilot project: design, implementation and future directions. Mult Scler 2017;24:1770-1772.

3. Mahad DH, Trapp BD, Lassmann H. Pathological mechanisms in progressive multiple sclerosis. Lancet Neurol 2015;14:183-193.

4. Vollmer T, Signorovitch J, Huynh L, et al. The natural history of brain volume loss among patients with multiple sclerosis: a systematic literature review and metaanalysis. J Neurol Sci 2015;357:8-18.

5. Franklin RJ, ffrench-Constant C, Edgar JM, Smith KJ. Neuroprotection and repair in multiple sclerosis. Nat Rev Neurol 2012;8:624-634.

6. Sahraian MA, Radue EW, Haller S, Kappos L. Black holes in multiple sclerosis definition, evolution, and clinical correlations. Acta Neurol Scand 2010;122:1-8.

7. Gaitán MI, Shea CD, Evangelou IE, et al. Evolution of the blood-brain barrier in newly forming multiple sclerosis lesions. Ann Neurol 2011;70:22-29.

8. Sweeney EM, Shinohara RT, Dewey BE, et al. Relating multi-sequence longitudinal intensity profiles and clinical covariates in incident multiple sclerosis lesions. Neuroimage Clin 2016;10:1-17.

9. Ghassemi R, Brown R, Narayanan S, Banwell B, Nakamura K, Arnold DL. Normalization of white matter intensity on T1-weighted images of patients with acquired central nervous system demyelination. J Neuroimaging 2015;25:184-190.

10. Shinohara RT, Sweeney EM, Goldsmith J, et al. Statistical normalization techniques for magnetic resonance imaging. Neuroimage Clin 2014;6:9-19.

11. Schmierer K, Scaravilli F, Altmann DR, Barker GJ, Miller DH. Magnetization transfer ratio and myelin in postmortem multiple sclerosis brain. Ann Neurol 2004;56: 407-415. 
12. Giacomini PS, Levesque IR, Ribeiro L, et al. Measuring demyelination and remyelination in acute multiple sclerosis lesion voxels. Arch Neurol 2009;66:375-381.

13. Chen JT, Collins DL, Atkins HL, Freedman MS, Arnold DL, Canadian MS/BMT Study Group. Magnetization transfer ratio evolution with demyelination and remyelination in multiple sclerosis lesions. Ann Neurol 2008;63:254-262.

14. Brown RA, Narayanan S, Stikov N, et al. MTR recovery in brain lesions in the BECOME study of glatiramer acetate vs interferon beta-1b. Neurology 2016;87:905-911.

15. Altmann DR, Button T, Schmierer K, et al. Sample sizes for lesion magnetisation transfer ratio outcomes in remyelination trials for multiple sclerosis. Mult Scler Relat Disord 2014;3:237-243.

16. Brown RA, Narayanan S, Atkins HL, Freedman MS, Arnold DL. Normalization of magnetization transfer ratio MRI for multicentre clinical trials. ISMRM 2011:4082.

17. Fox RJ, Cronin T, Lin J, et al. Measuring myelin repair and axonal loss with diffusion tensor imaging. AJNR Am J Neuroradiol 2011;32:85-91.

18. Fox RJ, Sakaie K, Lee JC, et al. A validation study of multicenter diffusion tensor imaging: reliability of fractional anisotropy and diffusivity values. AJNR Am J Neuroradiol 2012;33:695-700

19. MacKay A, Whittall K, Adler J, Li D, Paty D, Graeb D. In vivo visualization of myelin water in brain by magnetic resonance. Magn Reson Med 1994;31:673-677.

20. Faizy TD, Thaler C, Kumar D, et al. Heterogeneity of multiple sclerosis lesions in multislice myelin water imaging. PLoS ONE 2016;11:e151496.

21. Vargas WS, Monohan E, Pandya S, et al. Measuring longitudinal myelin water fraction in new multiple sclerosis lesions. Neuroimage Clin 2015;9:369-375.

22. Meyers SM, Vavasour IM, Mädler B, et al. Multicenter measurements of myelin water fraction and geometric mean T2: intra- and intersite reproducibility. J Magn Reson Imaging 2013;38:1445-1453

23. Kolind S, Matthews L, Johansen-Berg H, et al. Myelin water imaging reflects clinical variability in multiple sclerosis. Neuroimage 2012;60:263-270.

24. Nguyen TD, Spincemaille P, Gauthier SA, Wang Y. Rapid whole brain myelin water content mapping without an external water standard at 1.5T. Magn Reson Imaging 2017;39:82-88.

25. de Rochefort L, Liu T, Kressler B, et al. Quantitative susceptibility map reconstruction from MR phase data using Bayesian regularization: validation and application to brain imaging. Magn Reson Med 2010;63:194-206.

26. Kames C, Wiggermann V, Rauscher A. Rapid two-step dipole inversion for susceptibility mapping with sparsity priors. Neuroimage 2018;167:276-283.

27. Chen W, Gauthier SA, Gupta A, et al. Quantitative susceptibility mapping of multiple sclerosis lesions at various ages. Radiology 2014;271:183-192.

28. Wiggermann V, Hernández Torres E, Vavasour IM, et al. Magnetic resonance frequency shifts during acute MS lesion formation. Neurology 2013;81:211-218.

29. Hametner S, Wimmer I, Haider L, Pfeifenbring S, Brück W, Lassmann H. Iron and neurodegeneration in the multiple sclerosis brain. Ann Neurol 2013;74:848-861.

30. Wiggermann V, Hametner S, Hernández-Torres E, et al. Susceptibility-sensitive MR of multiple sclerosis lesions and the impact of normal-appearing white matter changes. NMR Biomed 2017;30.

31. Dal-Bianco A, Grabner G, Kronnerwetter C, et al. Slow expansion of multiple sclerosis iron rim lesions: pathology and $7 \mathrm{~T}$ magnetic resonance imaging. Acta Neuropathol 2017;133:25-42.

32. Absinta M, Sati P, Schindler M, et al. Persistent 7-tesla phase rim predicts poor outcome in new multiple sclerosis patient lesions. J Clin Invest 2016;126: 2597-2609.

33. de Paula Faria D, de Vries EF, Sijbesma JW, Dierckx RA, Buchpiguel CA, Copray S. PET imaging of demyelination and remyelination in the cuprizone mouse model for multiple sclerosis: a comparison between $[11 \mathrm{C}] \mathrm{CIC}$ and $[11 \mathrm{C}] \mathrm{MeDAS}$. Neuroimage 2014;87:395-402.

34. Stankoff B, Freeman L, Aigrot MS, et al. Imaging central nervous system myelin by positron emission tomography in multiple sclerosis using [methyl-(1)(1)C]-2-(4'methylaminophenyl)-6-hydroxybenzothiazole. Ann Neurol 2011;69:673-680.

35. Vowinckel E, Reutens D, Becher B, et al. PK11195 binding to the peripheral benzodiazepine receptor as a marker of microglia activation in multiple sclerosis and experimental autoimmune encephalomyelitis. J Neurosci Res 1997;50:345-353.

36. Nielsen AS, Kinkel RP, Madigan N, Tinelli E, Benner T, Mainero C. Contribution of cortical lesion subtypes at 7T MRI to physical and cognitive performance in MS Neurology 2013;81:641-649.
37. Derakhshan M, Caramanos Z, Narayanan S, Arnold DL, Louis Collins D. Surfacebased analysis reveals regions of reduced cortical magnetization transfer ratio in patients with multiple sclerosis: a proposed method for imaging subpial demyelination. Hum Brain Mapp 2014;35:3402-3413.

38. Nelson F, Poonawalla AH, Hou P, Huang F, Wolinsky JS, Narayana PA. Improved identification of intracortical lesions in multiple sclerosis with phase-sensitive inversion recovery in combination with fast double inversion recovery MR imaging. AJNR Am J Neuroradiol 2007;28:1645-1649.

39. Kilsdonk ID, Jonkman LE, Klaver R, et al. Increased cortical grey matter lesion detection in multiple sclerosis with $7 \mathrm{~T}$ MRI: a post-mortem verification study. Brain 2016;139:1472-1481.

40. Granberg T, Fan Q Treaba CA, et al. In vivo characterization of cortical and white matter neuroaxonal pathology in early multiple sclerosis. Brain 2017;140:2912-2926.

41. Mangeat G, Govindarajan ST, Mainero C, Cohen-Adad J. Multivariate combination of magnetization transfer, $\mathrm{T}^{*}$ and $\mathrm{B} 0$ orientation to study the myelo-architecture of the in vivo human cortex. Neuroimage 2015;119:89-102.

42. Arnold DL, De Stefano N, Narayanan S, Matthews PM. Proton MR spectroscopy in multiple sclerosis. Neuroimaging Clin N Am 2000;10:789.

43. Srinivasan R, Ratiney H, Hammond-Rosenbluth KE, Pelletier D, Nelson SJ. MR spectroscopic imaging of glutathione in the white and gray matter at $7 \mathrm{~T}$ with an application to multiple sclerosis. Magn Reson Imaging 2010;28:163-170.

44. Sammi MK, Berlow Y, West R, et al. Multiple sclerosis gray matter shows greater abnormalities in phosphate metabolites than white matter. ISMRM 2018.

45. Huang SY, Tobyne SM, Nummenmaa A, et al. Characterization of axonal disease in patients with multiple sclerosis using high-gradient-diffusion MR imaging. Radiology 2016;280:244-251.

46. Inglese M, Oesingmann N, Zaaraoui W, Ranjeva JP, Fleysher L. Sodium imaging as a marker of tissue injury in patients with multiple sclerosis. Mult Scler Relat Disord 2013;2:263-269.

47. Cifelli A, Arridge M, Jezzard P, Esiri MM, Palace J, Matthews PM. Thalamic neurodegeneration in multiple sclerosis. Ann Neurol 2002;52:650-653.

48. Minagar A, Barnett MH, Benedict RH, et al. The thalamus and multiple sclerosis: modern views on pathologic, imaging, and clinical aspects. Neurology 2013;80: 210-219.

49. Azevedo CJ, Cen SY, Khadka S, et al. Thalamic atrophy in multiple sclerosis: a magnetic resonance imaging marker of neurodegeneration throughout disease. Ann Neurol 2018;83:223-234.

50. Geurts JJ, Bö L, Roosendaal SD, et al. Extensive hippocampal demyelination in multiple sclerosis. J Neuropathol Exp Neurol 2007;66:819-827.

51. Kern KE A, Giesser BS, Montag M, Sicotte NL. Role of hippocampal connectivity in functional verbal memory compensation in multiple sclerosis. Mult Scler 2009; 15:S220.

52. Green AJ, McQuaid S, Hauser SL, Allen IV, Lyness R. Ocular pathology in multiple sclerosis: retinal atrophy and inflammation irrespective of disease duration. Brain 2010;133:1591-1601.

53. Button J, Al-Louzi O, Lang A, et al. Disease-modifying therapies modulate retinal atrophy in multiple sclerosis: a retrospective study. Neurology 2017;88:525-532.

54. Saidha S, Al-Louzi O, Ratchford JN, et al. Optical coherence tomography reflects brain atrophy in multiple sclerosis: a four-year study. Ann Neurol 2015;78:801-813.

55. Rocca MA, Horsfield MA, Sala S, et al. A multicenter assessment of cervical cord atrophy among MS clinical phenotypes. Neurology 2011;76:2096-2102.

56. Schlaeger R, Papinutto N, Panara V, et al. Spinal cord gray matter atrophy correlates with multiple sclerosis disability. Ann Neurol 2014;76:568-580.

57. Oh J, Sotirchos ES, Saidha S, et al. Relationships between quantitative spinal cord MRI and retinal layers in multiple sclerosis. Neurology 2015;84:720-728.

58. Absinta M, Vuolo L, Rao A, et al. Gadolinium-based MRI characterization of leptomeningeal inflammation in multiple sclerosis. Neurology 2015;85:18-28.

59. Zivadinov M, Ramasamy DP, Vaneckova M, et al.. Leptomeningeal contrast enhancement is associated with progression of cortical atrophy in MS: a retrospective, pilot, observational longitudinal study. Mult Scler 2017;23:1336-1345.

60. Shinohara RT, Oh J, Nair G, et al. Volumetric analysis from a Harmonized multisite brain MRI study of a single subject with multiple sclerosis. AJNR Am J Neuroradiol 2017;38:1501-1509.

References e61-e146 are available online at links.lww.com/WNL/A830.

\section{Subspecialty Alerts by E-mail!}

Customize your online journal experience by signing up for e-mail alerts related to your subspecialty or area of interest. Access this free service by clicking on the "My Alerts" link on the home page. An extensive list of subspecialties, methods, and study design choices will be available for you to choose from-allowing you priority alerts to cutting-edge research in your field! 